\title{
URINARY STONE RELATED URINARY TRACT INFECTION CAUSED BY RAOULTELLA ORNITHINOLYTICA IN A CHILD: A CASE REPORT
}

\author{
Mehmet Karaci ${ }^{1}$ and AdemYaşar ${ }^{2}$ \\ ${ }^{1}$ University of Medical Sciences, Şehit Prof. Dr. İlhan Varank Sancaktepe Training and Research Hospital, \\ Department of Pediatrics. Istanbul, Turkey; \\ ${ }^{2}$ Celal Bayar University, Faculty of Medicine, Department of Pediatrics, Allergy and Immunology, Manisa, Turkey \\ SUMMARY - Raoultella ornithinolytica is one of the three species of Raoultella. The present case \\ report describes a two-year-old child who had complaints of discomfort and fever, and Raoultella \\ ornithinolytica in his urinary culture. Grade-2 hydronephrosis and a $7.5-\mathrm{mm}$ urinary stone were \\ detected in the patient's left ureter. The stone was expelled upon consultation with pediatric urology \\ department. The patient was treated according to culture antibiotic sensitivity report and continued to \\ be followed-up.
}

Key words: Raoultella ornithinolytica; Urinary stone; Childhood; Urinary tract infection

\section{Introduction}

Urinary tract infection is any infection of a part of urinary tract ${ }^{1}$. Raoultella spp. are microorganisms which rarely cause infection in people, belong to Enterobacteriaceae family, are facultative gram (-), catalase $(+)$, oxidase $(-)$, capsule-free, immobile, and can produce histamine. This bacterium was first defined by Kosako et al. in $1989^{2}$. It is found in aquatic environments, fish and insects. Raoultella ornithinolytica $(R$. ornithinolytica) is a histamine-producing bacterium that causes fish poisoning ${ }^{3,4}$.

In this case report, a case in a child with complaints of discomfort and fever is described. The child was diagnosed with $R$. ornithinolytica in his urinary culture and left ureter stone in his urinary system, without any

\footnotetext{
Correspondence to: Assist. Prof. Mehmet Karaci, MD, University of Medical Sciences, Şehit Prof. Dr. İlhan Varank Sancaktepe Training and Research Hospital, Department of Pediatrics, Istanbul, Turkey; Emek mahallesi, Namık Kemal caddesi, 34785 Sancaktepe/İstanbul, Turkey

E-mail: mkaraci@gmail.com

Received January 27, 2016, accepted April 25, 2016
}

underlying predisposing reason, unlike cases in the literature. To our knowledge, this is the second childhood case of human infection with $R$. ornithinolytica reported in the literature.

\section{Case Report}

A 2-year-old male patient was admitted to pediatric polyclinic due to fever. History of the patient revealed that he also had fever one week before and had been treated for upper respiratory tract infection at another institution but developed fever again on the $7^{\text {th }}$ day of treatment. According to the patient's history, upon delivery by cesarean section, his birth weight was $3450 \mathrm{~g}$, length $50 \mathrm{~cm}$ and head circumference $35 \mathrm{~cm}$. He was hospitalized at the newborn intensive care unit for 7 days due to hyperbilirubinemia and neonatal sepsis on the postnatal day 4 , and there was no reproduction in the blood and urinary cultures. Afterwards, he did not have frequent admissions to hospital or hospitalization. There was no known disease in his family history. On physical examination, the values were as follows: body weight $12.5 \mathrm{~kg}\left(50^{\text {th }}\right.$ percentile $)$ and height $87 \mathrm{~cm}\left(25^{\text {th }}\right.$ - 


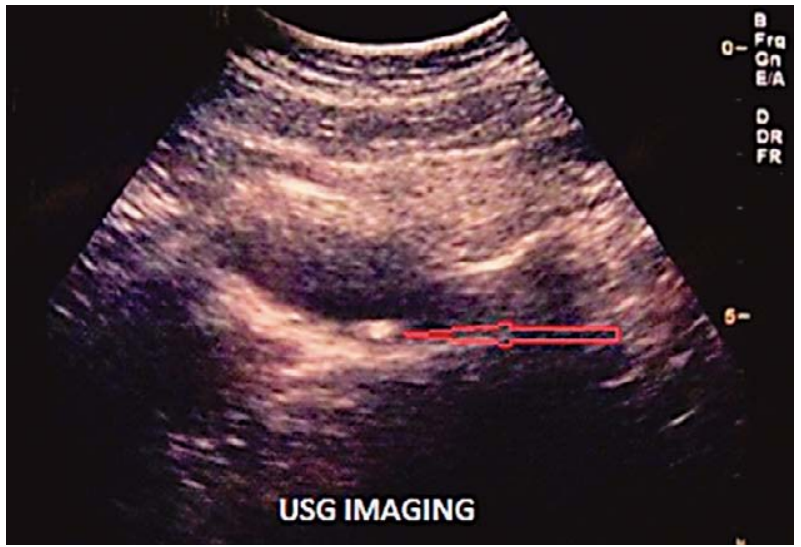

Fig. 1. Urinary stone ultrasound image.

$50^{\text {th }}$ percentile). Physical examination was normal and his body temperature was $37.2{ }^{\circ} \mathrm{C}$. Complete blood count showed the following values: WBC $19.2 \times 10^{3} / \mu \mathrm{L}$ (52.6\% neutrophil, 37\% lymphocyte); Hb10.7 g/dL; HTC 31.9\%; MCV 74 fL; RDW 16.8; Plt 332000x10/ $\mu \mathrm{L}$; C-reactive protein $3.04 \mathrm{mg} / \mathrm{dL}(0-0.5 \mathrm{mg} / \mathrm{dL})$; biochemical parameters were normal. Urine dipstick (with urine bag) was positive for leukocytes and negative for blood/hemoglobin, nitrite. There were 12-14 leukocytes and abundant amorphous crystals in every field in urinary sediment. Urinary system ultrasound revealed a $7.5-\mathrm{mm}$ stone and grade 2 hydronephrosis distally in the left ureter (Fig. 1). In his urinary culture, $\geq 10^{5} \mathrm{CFU} / \mathrm{mL}$ R. ornithinolytica was detected. According to the antibiotic sensitivity report, it was sensitive to trimethoprim/sulfamethoxazole, amoxicillin/clavulanic acid, gentamicin, cefuroxime axetil but resistant to ampicillin. For confirmation, urine sample and culture were obtained with a catheter under sterile conditions. Moreover, necessary tests for stone etiology were ordered and oral cefuroxime axetil was started in the patient. In urinary culture taken with the catheter, $10^{5}$
$\mathrm{CFU} / \mathrm{mL} R$. ornitbinolytica reproduced and the antibiotic sensitivity report was the same as the former one. The urine was cultivated on EMB and blood agar. The colonies proliferated in both agars selected for gram staining and gram-negative bacilli were isolated. Bacterial identification was carried out using the VITEK-2 compact system. Immunoglobulins of the patient were in the normal range for his age. In the tests performed for stone etiology, calcium/creatinine, oxalate, citrate, magnesium and uric acid values were in the proper range in the spot urine according to his age. Due to grade 2 hydronephrosis, his endoscopic stone was removed by a pediatric urologist and double J catheter was introduced. Follow-up of the patient having remission of hydronephrosis has been continued at the nephrology and pediatric urology clinics.

\section{Discussion}

In the literature, Raoultella spp. is reported only in sporadic cases as the pathogens responsible for human infections across the world. To our knowledge, there are four childhood cases including newborn cases. Notably, while primary or secondary immunodeficiency and serious diseases were detected in these children, there was no such etiologic cause in our case. The first human infection caused by $R$. ornithinolytica was reported in $2009^{3}$. Moreover, the first case in whose blood or urinary samples $R$. ornithinolytica reproduction was reported in the pediatric group was a preterm infant presenting with septic shock and purpura fulminans and dying at 19 days of age 5 . The second case of $R$. ornithinolytica presented with bacteremia, asplenia, congenital cardiac defects and visceral heterotaxy ${ }^{6}$. The third one was a 21-day-old male patient who was treated due to urinary tract infection ${ }^{7}$. The fourth patient was aged 8 years and

Table 1. Characteristics of Raoultella ornithinolytica cases reported in childhood

\begin{tabular}{|l|l|l|l|l|l|}
\hline Reference & Age/Sex & $\begin{array}{l}\text { Isolated } \\
\text { specimen }\end{array}$ & Clinical manifestation & Treatment & Outcome \\
\hline $\begin{array}{l}\text { Sandal and } \\
\text { Ozen, 2014 }\end{array}$ & $\begin{array}{l}\text { Preterm 19 days } \\
\text { / female }\end{array}$ & Blood & $\begin{array}{l}\text { Septic shock and purpura } \\
\text { fulminans }\end{array}$ & Meropenem + vancomycin & Died \\
\hline $\begin{array}{l}\text { Mau and Ross, } \\
2010^{6}\end{array}$ & 3 days / male & Blood & Bacteremia & Amikacin + meropenem & Recovered \\
\hline $\begin{array}{l}\text { Akyuz Ozkan } \\
\text { et al., 2014 }\end{array}$ & 21 days / male & Urine & Urinary tract infection & Amikacin & Recovered \\
\hline $\begin{array}{l}\text { Seckowska } \text { et al., } \\
2015^{8}\end{array}$ & 8 years / male & Blood & $\begin{array}{l}\text { Catheter-related blood } \\
\text { stream infection, septicemia }\end{array}$ & $\begin{array}{l}\text { Piperacillin + tazobactam } \\
+ \text { amikacin }\end{array}$ & Recovered \\
\hline
\end{tabular}


had R. ornithinolytica sepsis due to central venous catheter while in intensive care unit for retinoblastoma ${ }^{8}$. Characteristics of these cases are shown in Table 1.

A characteristic common to these cases is that all of them were newborn infants except for the last case. Immunosuppression was available in the last case as in the newborn infants. Our case, however, was a two-year-old child who had normal growth and development, did not have immunodeficiency, and was the first child in whose urinary culture this bacterium was isolated.

In addition, Chondros et al. ${ }^{9}$ isolated this agent in complicated urinary tract infection due to urinary stone in an adult case, as in our case. $R$. ornithinolytica was isolated from blood culture specimens in 16 adult cases. The majority of these patients had an underlying malignant condition of advanced stage (15 patients, $94 \%)^{10}$. Likewise, in another study, $R$. ornithinolytica was isolated in nine adult patients diagnosed with cys$\operatorname{titis}^{11}$. $R$. ornithinolytica is usually resistant to ampicillin. In the present case, ampicillin resistance was also recorded. We administered cefuroxime therapy to our patient for 10 days according to the antibiotic sensitivity report, and follow-up urine culture was negative.

In conclusion, this is the second childhood case except for the newborns reported in the literature, and urinary stone was found as the underlying etiology. Successful treatment with proper antibiotic was performed in this child. Although rarely seen in children, $R$. ornithinolytica may be a life-threatening infection, especially in newborns.

\section{References}

1. Dada OE, Akharaiyi FC, Lawal OZ. Bacteriuria among primary and secondary school pupils in Akure North Local Government Area of Ondo State, Nigeria. Acta Clin Croat. 2012;51:379-85.
2. Kosako Y, Tamura K, Sakazaki R, Miki K. Klebsiella ornitbinolytica sp. nov., formerly known as ornithine-positive Klebsiella oxytoca. Curr Microbiol. 1989;18:201-6. https://doi.org/ 10.1007/BF01570291

3. Morais VP, Daporta MT, Bao AF, Campello MG, Andrés GQ. Enteric fever-like syndrome caused by Raoultella ornithinolytica (Klebsiella ornithinolytica). J Clin Microbiol. 2009;47:868-9. https://doi.org/10.1128/JCM.01709-08

4. Haruki $Y$, Hagiya H, Sakuma A, Murase T, Sugiyama T, Kondo S. Clinical characteristics of Raoultella ornithinolytica bacteremia: a case series and literature review. J Infect Chemother. 2014;20(9):589-91. https://doi.org/10.1016/j.jiac.2014.05.005

5. Sandal G, Ozen M. Fatal Raoultella ornithinolytica sepsis and purpura fulminans in a preterm newborn. Indian J Paediatr Dermatol. 2014;15(1):24-6. https://doi.org/10.4103/23197250.131833

6. Mau N, Ross LA. Raoultella ornitbinolytica bacteremia in an infant with visceral heterotaxy. Pediatr Infect Dis J. 2010; 29(5):477-8. https://doi.org/10.1097/INF.0b013e3181ce9227

7. Akyuz Ozkan E, Khosroshahi HE, Yilmaz N, Gecit AU, Domur E. A rare case of a newborn with urinary tract infection by Raoultella ornithinolytica. Am J Health Res. 2014;2(6):3757. https://doi.org/10.11648/j.ajhr.20140206.19

8. Sękowska A, Dylewska K, Gospodarek E, Bogiel T. Catheterrelated blood stream infection caused by Raoultella ornithinolytica. Folia Microbiol (Praha). 2015;60(6):493-5. https://doi. org/10.1007/s12223-015-0390-2

9. Chondros K, Heretis I, Chondros N. A rare case of calculi-related acute pyelonephritis by Raoultella ornithinolytica. Sch J Med Case Rep. 2014;2(8):557-9.

10. Chun S, Yun JW, Huh HJ, Lee NY. Clinical characteristics of Raoultella ornithinolytica bacteremia. Infection. 2015;43(1):5964. https://doi.org/10.1007/s15010-014-0696-Z

11. Boattini M, Almeida A, Cardoso C, Cruz CS, Machado C, Vesza Z, et al.Infections on the rise: Raoultella spp., clinical and microbiological findings from a retrospective study, 2010-2014. Infect Dis (Lond). 2016;48(1):87-91. https://doi.org/10.3109/ 23744235.2015.1082619

Sažetak

\section{INFEKCIJA MOKRAĆNOG SUSTAVA POVEZANA S KAMENCEM UZROKOVANA BAKTERIJOM RAOULTELLA ORNITHINOLYTICA U DJETETA: PRIKAZ SLUČAJA}

\section{Karacı i A. Yașar}

Raoultella ornithinolytica je jedna od vrsta bakterije Raoultella. U ovom prikazu slučaja opisuje se dvogodišnje dijete koje je imalo tegobe i groznicu te bakteriju Raoultella ornitbinolytica u urinokulturi. U bolesnikovu desnom ureteru nađena je hidronefroza 2. stupnja i kamenac veličine 7,5 mm. Kamenac je izbačen u konzultaciji s pedijatrijskim urologom. Bolesnik je liječen prema antibiogramu, a njegovo stanje se i dalje prati.

Ključne riječi: Raoultella ornithinolytica; Kamenci mokraćnog sustava; Djetinjstvo; Infekcija mokraćnog sustava 